\title{
KEKERASAN TERHADAP ANAK, PENANAMAN DISIPLIN, DAN REGULASI EMOSI ORANG TUA
}

\author{
Dewi Eko Wati, dan Intan Puspitasari \\ Prodi PG PAUD Universitas Ahmad Dahlan Yogyakarta \\ dewiuad@gmail.com, intan.puspitasari@uad.ac.id
}

\begin{abstract}
Early childhood is an asset for the future of family, society, and nation because the quality of a nation is influenced by the quality of the children of the nation as a whole. Unfortunately, child abuse or violence is still occurs in many environments such as family level. The purpose of this study is to examine and to explore the factors causing child abuse at family level which mostly done by parents. The research method used qualitative approach. Data were collected by questionnaire and analyzed with qualitative descriptive technique. Sample selection was done by cluster sampling technique. The subjects of this research are the parents of children aged 4-6 years whom their children attend school in Kindergarten in Gondomanan cluster, Umbulharjo, Gedongtengen, and Ngampilan. The result shows that factors causing parents to do violence in the sub district of Umbulharjo, Ngampilan, Gondomanan and Gedongtengen is the psychological condition of immature parents in terms of self-emotional regulation.
\end{abstract}

Keywords: child abuse, discipline, emotional regulation

\begin{abstract}
Abstrak. Anak usia dini merupakan aset bagi masa depan keluarga, masyarakat dan bangsa karena kualitas suatu bangsa dipengaruhi oleh kualitas anak-anak bangsa secara keseluruhan. Sayangnya, kekerasan terhadap aset bangsa tersebut masih banyak terjadi. Kekerasan pada anak banyak terjadi pada level keluarga. Tujuan penelitian untuk mengkaji dan menggali tentang faktor penyebab kekerasan pada anak di level keluarga atau yang sering dilakukan oleh orang tua. Metode penelitian menggunakan pendekatan kualitatif. Pengumpulan data menggunakan angket dan teknis analisis data menggunakan analisis deskriptif kualitatif. Pemilihan sampel dengan teknik cluster sampling. Subjek penelitian ini ialah orang tua anak usia 4-6 tahun dimana anakanak mereka sekolah di Taman Kanak-Kanak di gugus Gondomanan, Umbulharjo, Gedongtengen, dan Ngampilan. Hasil penelitian menunjukkan di kecamatan Umbulharjo, Ngampilan, Gondomanan dan Gedongtengen faktor penyebab orang tua melakukan kekerasan ialah kondisi psikologis orang tua yang belum matang dalam hal regulasi emosi diri.
\end{abstract}

Kata kunci: kekerasan, disiplin, regulasi emosi

\section{Pendahuluan}

Kekerasan menurut Undang-Undang Republik Indonesia Nomor 35 Tahun 2014 tentang Perubahan Atas Undang-Undang Nomor 23 Tahun 2002 Tentang Perlindungan Anak Pasal 1 Ayat 15a merupakan setiap perbuatan terhadap anak yang berakibat timbulnya kesengsaraan atau penderitaan secara fisik, psikis, seksual, dan/atau penelantaran, termasuk ancaman untuk melakukan perbuatan, pemaksaan, atau perampasan kemerdekaan secara melawan hukum. Selain itu, Barker (dalam Huraerah, 2007: 47) juga mendefinisikan child abuse 
yaitu tindakan melukai berulang-ulang secara fisik dan emosional terhadap anak yang ketergantungan, melalui desakan hasrat, hukuman badan yang tak terkendali, degradasi dan cemoohan permanen atau kekerasan seksual, biasanya dilakukan para orangtua atau pihak lain yang seharusnya merawat anak.

Menurut Undang-Undang No 23 tahun 2002 pasal 16 ayat 1 tentang Perlindungan Anak kekerasan merupakan penganiayaan terhadap anak disertai dengan kekerasan fisik maupun emosional yang berdampak pada perkembangan anak. Anak yang sering mendapatkan kekerasan fisik maupun emosional akan menimbulkan masalah perilaku di usia-usia berikutnya. Misalnya sulit berkonsentrasi, malas sekolah, kurang percaya diri, mudah cemas, dan lain-lain.

Hasil survey KPAI pada tahun 2012 di 9 provinsi menunjukkan bahwa 91\% anak menjadi korban kekerasan di lingkungan keluarga, $87.6 \%$ di lingkungan sekolah dan $17.9 \%$ di lingkungan masyarakat. $78.3 \%$ anak melakukan kekerasan karena memiliki pengalaman sebagai korban kekerasan sebelumnya (Setyawan, 2015).

Pelaku kekerasan anak lebih banyak dilakukan oleh orang-orang yang seharusnya menjadi pelindung bagi anak itu sendiri, misalnya orang tua, kerabat dekat, tetangga, hingga guru (Menkokesra, 2013). Hal ini terjadi karena banyak orangtua menganggap kekerasan pada anak merupakan bagian dari mendisiplinkan anak (The National Child Traumatic Stress Network, 2009).

Disiplin berasal dari kata "disciple" artinya seseorang mengikuti pimpinan secara sukarela. Menurut Kostelnik, dkk (2007) disiplin adalah perilaku yang dilakukan tanpa adanya paksaan dengan tujuan untuk individu mampu memahami dan membedakan perilaku yang benar dan yang salah serta mentaati peraturan tanpa adanya reward dan punishment.

Penanaman disiplin pada anak memang penting. Hal ini dilakukan untuk membentuk karakter yang akan bermanfaat untuk kehidupan anak kelak di kemudian hari. Pemberian disiplin perlu dilakukan secara efektif dan tepat supaya tidak menimbulkan masalah dikemudian hari.

\section{Metode}

Penelitian ini dilakukan dengan menggunakan pendekatan kuantitatif dan kualitatif. Pendekatan kualitatif dengan menggunakan metode analisis isi dan pendekatan kuantitatif dengan menggunakan analisis deskriptif. Peneliti menggunakan angket untuk melakukan pengambilan data lalu menganalisanya secara statistik dan menguraikannya secara deskriptif. Analisa statistik dilakukan dengan menghitung berapa banyak aitem pertanyaan tersebut dijawab oleh subjek. Populasi penelitian ini sejumlah 3200 orang yang tersebar di beberapa kecamatan di kota Yogyakarta. Peneliti menggunakan teknik cluster sampling untuk menentukan kecamatan mana yang akan diambil dengan mempertimbangkan banyaknya jumlah Taman Kanak-Kanak dan murid yang ada di wilayah tersebut. Peneliti mengambil kecamatan Gondomanan, Umbuljarjo, Ngampilan, dan Gedongtengen dengan masing-masing kecamatan berjumlah sekitar 110 orang tua. Pengambilan subjek penelitian menggunakan kriteria $10 \%$ dari total poplasi (Krejick dan Morgan dalam Sugiyono, 2011). Sehingga subjek penelitian ini berjumlah 320 orang.

\section{Hasil dan Pembahasan}

Data dalam penelitian ini diperoleh dari 330 responden yang merupakan orangtua dari anak dengan kisaran usia 4-6 tahun. Pengambilan data dilakukan di empat kecamatan yaitu Gondomanan, Umbulharjo, Gedongtengen dan Ngampilan. Masing-masing kecamatan dengan jumlah responden kurang lebih 80 responden. Grafik 1 menunjukkan penyebab tindak kekerasan orang tua terhadap anak. 


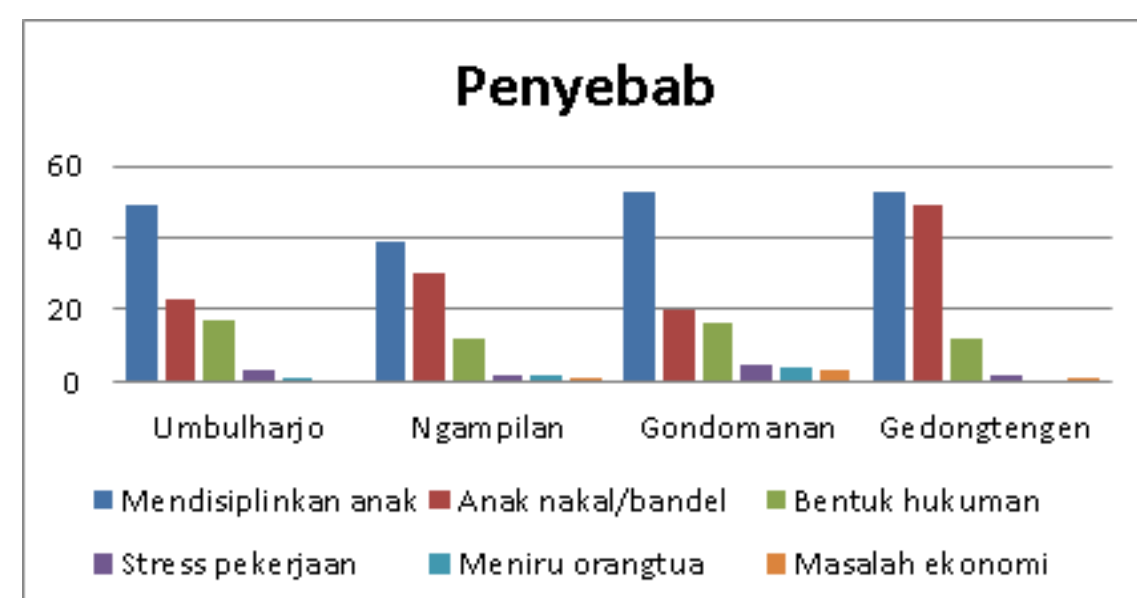

Grafik 1. Penyebab Tindak Kekerasan

Penyebab paling tinggi orang tua melakukan kekerasan terhadap anak adalah untuk mendisiplinkan anak. Kebanyakan orang rua masih melakukan tindak kekerasan dengan tujuan tersebut padahal menurut Slade \& Wissow (2004) hukuman fisik akan menyebabkan anak mengalami permasalahan di kemudian hari. Artinya hukuman fisik atau kekerasan fisik termasuk juga kekerasan emosional tidak efektif untuk membentuk disiplin pada anak. Tujuan disiplin adalah untuk membentuk karakter anak. Penanaman dispilin idealnya dilakukan sejak masih anak-anak. Penanaman displin sebaiknya dilakukan dengan pendekatan positif tanpa kekerasan.

Faktor penyebab orang tua melakukan tindak kekerasan terhadap anak ialah (Kurniasari,2015):

\section{Kondisi kepribadian}

Kondisi kepribadian orang tua sangat berpengaruh terhadap terjadi atau tidaknya tindak kekerasan terhadap anak. Kondisi kepribadian tersebut meliputi kepribadian yang matang, kemampuan diri dalam mengatasi tekanan emosional, dan atau kekecewaan.

Sejalan yang dikemukakan oleh Lundahl, Nimer, dan Parsons (2006) bahwa faktor yang mempengaruhi kekerasan pada anak antara lain penyesuaian emosi orangtua, sikap orangtua terhadap pengasuhan, dan perilaku orangtua saat mengasuh anak. Kekerasan terhadap anak juga disebabkan oleh tingkat pengetahuan orang tua seperti yang diungkapkan oleh Fitriana, Pratiwi, dan Sutanto (2015) menemukan bahwa beberapa faktor yang menyebabkan orangtua melakukan kekerasan antara lain tingkat pengetahuan, sikap, pengalaman dan pengaruh lingkungan.Dalam hal ini orangtua dilihat sebagai faktor utama ketika terjadi kekerasan terhadap anak. Dalam penelitian ini didapatkan data bahwa alasan orangtua melakukan kekerasan adalah untuk mendisiplinkan anak dan karena orangtua menganggap anaknya bandel atau nakal. Namun demikian orangtua perlu memiliki pengalaman belajar (Gross, 1999), sikap dan perilaku pengasuhan yang baik (Parke dalam Brenner \& Salovey, 1997) serta dapat menyesuaikan emosi ketika mengasuh anak. Unsur-unsur tersebut terdapat dalam regulasi emosi.

Regulasi emosi adalah kemampuan individu agar tetap tenang ketika berada di bawah tekanan (Reivich \& Shatte, 2002). Chen (2016) mengatakan bahwa regulasi emosi adalah proses seorang individu dalam mengatur dan mengubah emosi dirinya atau orang lain. Kaitannya dengan penelitian yang sedang dilakukan ini adalah orangtua telah mengetahui bahwa kekerasan pada anak sebaiknya tidak dilakukan. Namun pada kenyataannya kekerasan fisik menjadi bentuk kekerasan terbanyak yang ditemukan. Dan setelah melakukan mayoritas orangtua merasa menyesal telah melakukan hal tersebut. Hal ini menunjukkan adanya 
ketidaksesuaian antara kognisi (berupa informasi), psikomotor (perilaku kekerasan) dan afeksi (penyesalan). Oleh karena itu, sebagaimana yang disebutkan oleh Chen (2016) bahwa strategi regulasi emosi dapat dilakukan dengan penilaian kognitif (cognitive appraisal) dan penghambatan ekspresi (expression inhibitation).

\section{Kondisi sosial}

Kondisi ini meliputi kondisi sosial ekonomi dan lingkungan yang tidak nyaman. Kondisi tersebut membuat anggota keluarga atau anggota masyarakat rentan stress. Sehingga mereka melampiaskan tekanan emosional tersebut kepada anak-anak mereka dengan beralasan sebagai efek dari peilaku buruk anak-anak.

Lingkungan disebutkan sebagai salah satu faktor adanya kekerasan (Fitriana, Pratiwi dan Sutanto, 2015). Individu yang tinggal di lingkungan dimana banyak terjadi kekerasan maka individu tersebut rentan melakukan atau mengalami kekerasan itu sendiri. Data penelitian ini menunjukkan bahwa angka kekerasan pada anak dari empat Kecamatan didominasi oleh Kecamatan Gedongtengen. Hal ini dapat dikaji lebih dalam dengan melihat lingkungan dan kondisi di Kecamatan tersebut. Kecamatan ini memiliki dua kelurahan yaitu Kelurahan Sosromenduran dan Kelurahan Pringgokusuman. Dalam dua kelurahan ini terdapat beberapa tempat strategis seperti Stasiun Tugu dan Malioboro. Di sekitar tempat strategi ini terdapat beberapa lokalisasi seperti Pasar Kembang dan Bong Suwung. Pratama (2016) menemukan bahwa di sekitar Bong Suwung tersebut tinggal preman-preman dan gali-gali yang identik dengan kekerasan. Hal ini disebabkan karena tempat ini merupakan lokalisasi prostitusi kelas menengah ke bawah sehingga konsumen atau pemakai merupakan buruh dan kuli.

Setyaningrum dan Nasiwan (2017) menyebutkan bahwa Kelurahan Pringgokusuman, Kecamata Gedontengen merupakan tempat strategis yang mudah diakses sehingga mempunyai sisi positif dan negatifnya. Sisi positifnya tempat ini dekat dengan pusat pemerintahan kota dan fasilitas umum. Sementara sisi negatifnya tempat ini telah terpengaruh dengan budaya yang tidak sesuai dengan budaya Indonesia seperti seks bebas, hedonisme, minum-minuman keras dan penggunaan obat-obatan terlarang. Osborne dan Berger (2009) menemukan bahwa anak-anak yang tinggal dengan orangtua yang mengonsumsi obat-obatan terlarang dan minuman keras mempunyai risiko tinggi terhadap kesehatan yang buruk dan perilaku bermasalah.

Beberapa data dan analisis di atas dengan demikian dapat digunakan untuk menjawab pertanyaan penelitian ini yaitu faktor-faktor penyebab terjadinya kekerasan pada anak. Sebagaimana yang telah dipaparkan di atas bahwa orangtua di empatKecamatan ini paling banyak melakukan kekerasan terhadap anak dalam bentuk mencubit. Kemudian alasan orangtua melakukan kekerasan terhadap anak bertujuan untuk mendisiplinkan anak.

Penelitian ini selain menggali tentang faktor penyebab kekerasan pada anak, peneliti juga menggali tentang bentuk-bentuk kekerasan pada anak. Terdapat tiga bentuk kekerasan dengan jumlah respon terbanyak adalah mencubit (153), memelototi (145) dan membandingkan dengan anak lain (101). Dalam hal ini mencubit merupakan salah satu bentuk kekerasan fisik sementara memelototi dan membandingkan dengan anak lain termasuk dalam kekerasan non-fisik. Secara keseluruhan untuk kekerasan fisik terdapat 311 respon dan untuk kekerasan non fisik terdapat 362 respon. Pola asuh keluarga mempunyai pengaruh yang signifikan terhadap perkembangan individu. Menurut Baumrind (1966) menyatakan bahwa pengasuhan yang menggunakan model hukuman baik secara fisik maupun non fisik bukan merupakan cara yang efektif dalam mengontrol perilaku anak dan memiliki efek samping yang buruk. 


\section{Pengalaman kekerasan masa lalu}

Orang tua merupakan model bagi pengasuhan anak-anak mereka kelak ketika sudah dewasa. Orang tua yang pernah mengalami kekerasan di masa lalu maka akan cenderung melakukan kekerasan pada anakanak mereka sekarang. Pengalaman kekerasan yang diterima orang tua mereka waktu kecil dianggap sebagai cara mendisiplinkan anak.

\section{Proses sosialisasi}

Proses sosialisasi mempunyai pengaruh dalam munculnya perilaku agresi. Anak-anak adalah seorang imitatior ulung yang dengan mudah mereka akan meniru kata-kata maupun perilaku kasar yang diterimanya. Anakanak yang dalam interaksi sosialnya mendapatkan kekerasan maka mereka akan menganggap hal itu adalah benar dan akan dibawa sampai mereka dewasa.

\section{Penanaman Disiplin Pada Anak}

Disiplin adalah cara yang dilakukan oleh orang dewasa untuk mengajarkan kepada anak-anak perilaku yang benar dan salah supaya bisa berperilaku yang diterima oleh masyarakat. Cara ataupun upaya yang bisa dilakukan oleh orang tua, guru, atau orang dewasa lainnya untuk mendisiplinkan anak yaitu dengan memberikan stimulasi dan intervensi agar anak mengetahui perilakuperilaku tersebut. Penanaman disiplin berdasarkan usia sebagai berikut:

1. Pada masa bayi (0-3 tahun). Pada usia ini anak diajarkan tentang mana yang benar dan mana yang salah. Jika mereka melakukan perbuatan yang baik maka berilah penghargaan. Hukuman boleh diberikan jika bertujuan untuk mendidik namun jangan buru-buru diberikan.

2. Masa kanak-kanak awal (3-8 tahun). Pada usia ini penanaman disiplin lebih ditujukan untuk menanamkan tanggung jawab dan rasa hormat terhadap orang lain

Disiplin yang positif akan mendorong anak untuk mencapai kemampuan mengontrol diri dan melakukan disiplin secara sukarela. Sedangkan disiplin yang negatif, yang dilakukan dengan kekerasan, akan berdampak negatif terhadap perilaku dan kepribadian anak.

\section{Kesimpulan}

Disiplin merupakan cara yang dilakukan oleh orang tua, guru, ataupun orang dewasa lain untuk mengajarkan kepada anak tentang perilaku benar dan salah.. Penyebab paling tinggi orang tua melakukan kekerasan terhadap anak adalah untuk mendisiplinkan anak. Penanaman disiplin memang penting namun perlu dilakukan dengan acara yang positif dan efektif bukan dengan kekerasan. Penanaman disiplin dengan kekerasan justru akan membuat kondisi perilaku dan psikologis anak menjadi tidak baik. Untuk menanamkan disiplin tanpa kekerasan orang tua perlu menjadi pribadi yang matang secara psikologis atau regulasi emosi yang baik agar tidak mudah terpancing emosi oleh perilaku anak yang dianggap "nakal ataupun bandel". Regulasi emosi yaitu kemampuan individu untuk tetap tenang ketika berada dibawah tekanan.

Penanaman disiplin pada anak memang penting. Hal ini dilakukan untuk membentuk karakter yang akan bermanfaat untuk kehidupan anak kelak di kemudian hari. Pemberian disiplin perlu dilakukan secara efektif dan tepat supaya tidak menimbulkan masalah dikemudian hari. Dan yang terpenting ialah penanaman disiplin tanpa kekerasan pada anak. 


\section{Daftar Pustaka}

Baumrind, D. (1966). Effects of authoritative parental control on child behavior. Child Development, 37(4), 887-907

Fitriana, Y., Pratiwi, K., \& Sutanto, A.V. (2015). Faktor-faktor yang berhubungan dengan perilaku orangtua dalam melakukan kekerasan verbal terhadap anak usia pra-sekolah. Jurnal Psikologi Undip, 14(1), 81-93

Huraerah, Abu. (2007). Child Abuse (Edisi Revisi). Bandung: Nuansa.

Kurniasari, Alit. (2015). Kekerasan Versus Disiplin Dalam Pengasuhan Anak. Jakarta: Kementrian Sosial RI

Kostelnik, dkk. (2007). Developmentally Appropriate Curriculum. Ohio: Pearson

Republik Indonesia. Undang-Undang Nomor 35 Tahun 2014 Tentang Perubahan Atas Undang-Undang Nomor 23 Tahun 2002 TentangPerlindunganAnak.

Setyaningrum, I. \& Nasiwan, Dr. (2017). Pembentukan karakter anak melalui program jam belajar masyarakat $R W 01$ Jlagran Kelurahan Pringgokusuman Kecamatan Gedongtengen Yogyakarta (Skripsi). Diunduh dari Journal UNY. (8551).

Setyawan, D. (2015). KPAI: Pelaku Kekerasan Terhadap Anak Tiap Tahun Meningkat. Diakses dari www.kpai.go.id

Sugiyono. (2011). Statistika Untuk Penelitian. Bandung: Alfabeta

The National Child Traumatic Stress, Network, Physical Abuse Collaborative Group. (2009). Child physical abuse fact sheet. Los Angeles, CA \& Durhma, NC; National Center for Child Traumatic Stress. 